\title{
Relationship Between Multiple Intelligence and Career Interest Among Secondary School Students
}

\author{
Azriah Mohd Azmir ${ }^{1}$, Ku Suhaila Ku Johari ${ }^{1 *}$, Izwan Mahmud ${ }^{1}$ \\ ${ }^{1}$ Universiti Kebangsaan Malaysia, Bangi, Malaysia. \\ *Corresponding author. Email: suhaila@ukm.edu.my
}

\begin{abstract}
Intelligence is one ability to respond successfully to a new situation and the capacity to learn from one's past experiences. While interest is a strong motivation that drives actionsanddetermined by personality factors. This study aims to observethe relationship between multiple intelligence and career interests among secondary students. It used correlation methodto identify the relationship between multipleintelligence variables and career interests. All77 Form Three students were involved in this study. The research instruments used were Multiple Intelligence Inventory and Career Interest Inventory. This data was analysed by using a Pearson statistical correlation type ofSPSS Version 23. The finding of this study shows that there isamoderate and significant relationship between multiple intelligence and career interest. This finding also shows that the higher intelligence range, the more congruent personality patterns. This implies the tendency of personality patterns as a predictor of emotional intelligence. Further studyis suggested to useanappropriate and structured intervention in research methodology.
\end{abstract}

Keywords: Multiple intelligence, career interest

\section{INTRODUCTION}

Intelligence theory recognizes that all intelligence in each individual, and it has advantages when applied in education. This is because of multiple intelligences is acting as a guide to potential students. Each individual has all of the multiple intelligences. Most individuals can develop each intelligence to a higher level through training and self-ability. Each of the multiple intelligences interact with each other simultaneously. Meanwhile, all people intelligent in his own field. There are many ways to learn effective and it depends on the intelligence of the individual. Intelligence proposed by Gardner is as follows:

1.1 Verbal Linguistics (Word Intelligence)

1.2 Visual - Spatial (Visual and Space Intelligence)

1.3 Mathematical Logic (Number Intelligence)

1.4 Music (Music Intelligence)

1.5 Naturalist (Nature Intelligence)

1.6 Kinesthetic - Physical (Physical

1.7 Intelligence)

1.8 vii Interpersonal (Social Intelligence)

1.9 Intrapersonal (Self Intelligence)

1.10 Existential (Existence Intelligence)

Career Interest Inventory is based on the Theory of Career Typology Holland (1985). This theory has three main components namely individual needs, environment and harmony between the individual and the environment. Career selection is based on the personality of an individual and a few other variables on the background of the work (Holland, 1973). The basis used in this theory is:

1.1 Career selection is based on the expression of individual personality as well as the suitability of the work environment

1.2 One's interest is born of her personality

1.3 Individuals of the same type of work have in common in terms of personality

1.4 The harmony between personality and environment will improve work performance, performance, stability and job satisfaction

Holland Career Typology Theory

(1996) highlighted four assumptions which are:

1.1 All individuals can be categorized into one of six personality types, namely Realistic (R), Investigative (I), Artistic (A), Social (S), Enterprising (E) and Conventional (K). Each personality traits resulting from the interaction between different cultures, races and individuals' pressure, including peer, social class, cultural and physical environment. Such situation would cause interest among individual.

1.2 There are six types of work environments that support individual personalities and dominated by a certain type of personality that is both realistic (R), Investigative (I), Artistic (A), 
Social (S), Enterprising (E) and Conventional (K). Summary for the six types of work environment is RIASEK.

1.3 Individuals will find work environment or career in accordance with personality that allows them to express their skills and abilities as well as attitudes and values. Individuals will feel satisfied if they can adapt in such environment. For example, individuals who have a realistic personality will feel satisfied if able to work in realistic environments as well.

1.4 Behavior of an individual can be determined by the interaction between personality and environment criteria. If we know about the personality and the environment indirectly, we will be able to predict some of the things related to career choice, career achievement, competence, behavior and social education and employment exchange.

According to Holland (1985), satisfaction in choosing a career is liking his own personal orientation. This means that the job satisfaction is achieved when individuals choose a career in line with the personality and environment. Satisfaction is achieved when an individual creates a strong employment orientation. If the orientation of the career-built duality, likely achieved satisfaction will decrease.

\section{Multiple Intellingce}

Mohd Kashfi Mohd Jailani, Rosseni Din, SitiRahayahAriffin, Muhammad Amirul Abdullah, NorlizaGhazali, Ida Kamalawati Abu Bakar, Shah NazimShahar (2013) conducted a study of Multiple Intelligences (MI) and Learning Style (LeS) Among Public Higher Education Institution Students. Results showed multiple intelligences highest mean score for Social Sciences was spiritual domain, while the lowest score for Health Sciences was visual-space domain. For learning style, Social Sciences showed the highest mean score in collaborative learning style, while the lowest mean score is to avoid learning styles.

The study of correlation between multiple intelligences and English reading skills among Universiti Teknologi MARA Business Administration Students by Nuramirah Zaini, Norizan Abdul Razak (2013) showed a significant correlation between VisualSpatial intelligence with student performance in Business Management especially in reading comprehension and in non-linear textformat. In addition, there is a significant correlation between intelligence with linear text. While, study by Wahyudi (2016) found that there were no significant differences between intelligence based on demographic factors except vocational education level of respondents' parentsPearson correlation analysis showed that there is a strong relationship between realistic tendency with realistic competency and artistic tendencies with artistic competence.

The study of Multiple Intelligences Factors in Formation of Youth Profile by Siti Rahayah Ariffin, RoseniAriffin, Arbaiyah Md Zin, NikNoral hudaNik Mohamed (2011) aims to identify the contribution of the factors of multiple intelligences (KP) to eight multiple intelligences pioneered by Gardner. This study also aims to explore the different factors of multiple intelligences based on gender, race, schools, streams and SES (Social Economic Status). The implications of the study showed that teachers and school administrators should be sensitive to different multiple intelligences of each student. Teachers should make full use of the school infrastructure to tap this intelligence to maximize student performance.

\section{Career Interest}

Some studies discuss the relevance of previous studies to be a major in the study. Study on the Theory of Career Choice of Holland has been widely carried out. There are studies that supports it and vice versa. Among the studies that supports are Wall, Osipowand Ashby (1967), and Jones (1973). According to study by Monroe and Thomas (1981) towards 158 male students using the Vocational Preference Inventory (VPI), the problem relates to the field of engineering where students are oriented to Investigative and Realisticpersonality have interests and abilities in the field. Results showed that Investigative and Realistic personality type supports most in engineering.

In Malaysia, studies that relate between career alignment has much been discussed. One of the studies by Mohd. Amin (1987) conducted a study among boarding school pupils and mainstream secondary school. Results showed there were some significant between personality types and the choice among all students. While in terms of gender, there were no significant relationship but there is a significant difference in selection among male and female students.

Nazmi Md. Noor (1991) has run his studies among Bachelor of Education (Guidance and Counseling) and Bachelor of Education (Agricultural Science) students. Studies show there is significant alignment between personality and the field of study with Alignment Index (CI), each worth 8 and 6 . In addition, his research also found that there was no significant difference in personality patterns between male and female.

Studies conducted by AngHwi Lin (1981) towards 86 first year student of UniversitiKebangsaan Malaysia using the Rothwell-Miller Interest Blank (RMIB) and California Psychological Inventory (CPI)shows the relationship between personality and career interests as a whole is not significant. Results also shows that students have Investigative, Social and Conventionalpersonality. However, pupils who belong to Enterprising and Realistic personality show a 
significant relationship in career selection. The difference in the selection of male and female was also obtained.

\section{METHOD}

This study used a correlational study design to measure the relationship between multiple intelligence and career interests. Quantitative studies usually focused on the study of relationships and interactions between variables. It also focuses on research that facilitate understanding of the problem or a complex situation through the scientific method (Mok Soon Sang, 2010). Chua Yan Piaw (2006), states that survey studies can collect direct responses from the subjects. This method can be used to make predictions about current community issues that arise. The survey method is to identify the relationship between multiple intelligences of students with career interests. This method can help researchers viewed as the ability to generalize the findings to the population with accurate and effective. The study population comprised 424 students with a total of 198 male students and 226 female students at SMK DatoUndangSyed Ali Al Jufri, Jelebu. Students involved are in the age range of 15-16 years. The researcher has chosen sampling using random sampling method and the researcher agrees to select a stratified random sampling method of selecting respondents who are uniform. Samples were randomly selected from the overall number of students. Table 1 shows 77number of samples collected which includes all form 3 students in the schools. According to Mohd Majid Konting (1990), the sample size is not important. Most important is the sampling must be done effectively to allow the result to represent the population.

Table 1: Distribution of Subjects According to Gender School Male FemaleTotal

$\begin{array}{llll}\text { SMKDUSAJ } & 34 & 43 & 77\end{array}$

Research Instrument

This study uses Multiple Intelligences Inventory (IKP) and Career Interest Inventory (IMK) developed by the Ministry of Education Examination Board as resarch instrument. IKP and IMK is used to gather information about multiple intelligences and career interests.

\subsubsection{Inventory of Multiple Intelligences}

Multiple Intelligences Instrument (IKP) was used to obtain or gather information about the students. This instrument was developed based on the theory of Multiple Intelligences (MI) by Howard Gardner (1985) and Smith and Smith (2002). The instrument consists of Paper 1 and Paper 2. Paper 1 consists of Section A that contain 20 items to testMalay Language Verbal
Linguistics (30 minutes) and 20itemsto test English Verbal Linguistics (30 minutes). Part B has 20items which test Logical-Mathematical (30 minutes) and 10items on Visual-space (20 minutes). Students are required to answer in OMR form byshading the accurate answers. Paper 2 consists of 130 items representing constructs of Visual-Spatial, Music, Naturalist, Intrapersonal, Interpersonal, Kinestheticand Existential. Students have to answer YES or NO to the statement about themselves. The duration is 45 minutes.

Interpretation of scores obtained from students in connection with the agreement to a statement of intelligence shown in Table 3:29. Norm is always used to describe the position of a score compared with other scores (Tuckman, 1999). Based on the standard norms, score of $50 \%$ is considered to be a mean score, while a score of $75 \%$ or above is considered within the highest quartile (Gay \&Airasian, 2003). Thus, the interpretation of percent is made as shown in Table 2 .

Jadual2: Percentage Score Interpretation Percentage Score Interpretation

$$
\begin{aligned}
& 75 \% \text { to } 100 \% \\
& 50 \% \text { to } 74 \%
\end{aligned}
$$$$
0 \text { to } 49 \%
$$

Source: Alias Baba (1999), Tuckman (1999) and Gay \&Airasian (2003) inMohdSani Ismail (2009).

\subsubsection{Career Interest Inventory}

Career Interest Inventory (IMK) was developed by the Examination Board based on Career Interest Inventory (MoE, 2012). Some improvements have been made with the use of graphics and lighting to enhance the students' understanding of the information to be communicated. The new component is added to this inventory is efficiency in Part C. IMK Form 3 has three parts, Part A: Passions, Part B: Works, Part C: Skills.

IMK contains 6 constructs which are Realistic (R), Investigative (i), Artistic (a), Social (s), Enterprising (E) and Conventional $(\mathrm{k})$. Each construct has 30 items and the total number of items is 180 . IMK should be completed within 30 to 40 minutes. Administration of the inventory was conducted in a conducive and equipped room with basic amenities such as chairs and tables. All instructions should be followed and respected by students who take the test.

\subsubsection{Instrument Validity and Realibility}

According to Sidek (2005), a measurement device has high reliability if the individual has the same score by answering the same measuring devices at different times. Mejia, Balkin and Cardy (1998) in Sidek (2005) has defined the reliability of consistency measurements. Meanwhile, Mohd Majid (1990) in Sidek (2005), 
interpreting the validity of a measuring instrument refers to the extent to which an instrument measures the size of the data that should be measured.

Career Interest Inventory (IMK) has recognized its validity and have very high reliability with Alpha Cronbach value of $>0.8$. The validity and reliability of the high point of both inventories is suitable to be use in this study. As noted by Sidek (2005), based on test and measurement expert views from inside and outside the country, the reliability coefficient measurement tool that can be used with lowest score .50 and highest is 90 .

Multiple Intelligences Instrument (IKP) has been pre-tested to Form 3 students in secondary schools in Malaysia and using stratified sampling method. Schools samples consisting of secondary schools in urban, suburban, rural and high-performance, mediumperformance and low-performance. The selection of students as respondents also considering gender, race and performance. Data were analyzed to obtain the index KR-20 reliability and validity of the items that fit mean square (MNSQ).

\section{FINDINGS}

Findings show that there is a relationship between multiple intelligences with each construct of career interests. There are 5 construct of multiple intelligences that has a significant positive relationship with the realisticcareer interests construct which is significant positive relationship between the visual space with realistic $(\mathrm{r}=.425, \mathrm{p}<.05)$. These findings demonstrate that realistic career interests require visual intelligence space. In addition, there is a significant positive relationship between naturalist with realistic $(\mathrm{r}=.366, \mathrm{p}$ $<.05)$. These findings demonstrate that realistic career interests require naturalist intelligence. A significant positive relationship between the realistic kinesthetic ( $\mathrm{r}$ $=.436, \mathrm{p}<.05)$. This clearly shows that a realistic career interests require kinesthetic intelligence. There is a significant positive relationship between interpersonal and realistic $(\mathrm{r}=.290, \mathrm{p}<.05)$. These findings demonstrate that requires interpersonal realistic career interests. A significant positive relationship between intrapersonal and realistic $(\mathrm{r}=.425, \mathrm{p}<.05)$, this suggests that a realistic career interests require intrapersonal.

Constructs for investigative career interests also showed a significant correlation with the 4 constructs in Inventory of Multiple Intelligences, namely a significant positive relationship between the visual space with investigative $(r=.262, \mathrm{p}<.05)$. This finding indicates that an investigative career interests require visual-space intelligence. There is significant positive relationship between the investigative and naturalist ( $\mathrm{r}$ $=.420, \mathrm{p}<.05)$. This finding indicates that an investigative career interests require naturalist. There is also a significant positive relationship between interpersonal and investigative $(r=.358, p<.05)$. This finding indicates that an investigative career interests require interpersonal Moreover, there is a significant positive relationship between intrapersonal and investigative $(\mathrm{r}=.379, \mathrm{p}<.05)$.

There is only one constructs have a significant positive correlation with artistic construct which is music $(r=.425, p<.05)$. This finding clearly shows that artistic career requires music.

For the social construct of career interest, there is a significant positive relationship between the naturalist and social $(\mathrm{r}=.376, \mathrm{p}<.05)$. These findings demonstrate that social career interests require naturalist. A significant positive correlation between the social kinesthetic $(\mathrm{r}=.322, \mathrm{p}<.05)$. This finding indicates that the career interests of social need kinesthetic intelligence. There is a significant positive relationship between interpersonal and social $(\mathrm{r}=.388$, $\mathrm{p}$ <.05). These findings demonstrate that requires interpersonal social career interests. In addition, there is a significant positive relationship between intrapersonal and social $(\mathrm{r}=.367, \mathrm{p}<.05)$. This finding indicates that the career interests of social need visual-space intelligence. A significant positive correlation between the social and existential $(\mathrm{r}=.314, \mathrm{p}<.05)$. Finding shows that social interest career needs existential.

Enterprising career interest construct also haspositive significant relationship between enterprising and naturalist $(\mathrm{r}=.259, \mathrm{p}<.05)$. This finding indicates that enterprising career interests require naturalist. In addition, there is a significant positive relationship between the kinesthetic and enterprising $(\mathrm{r}=.336, \mathrm{p}<.05)$. This finding indicates that enterprising career interests require visual-space intelligence. There is significant positive relationship between interpersonal and enterprising $(r=.266, p$ <.05). This finding indicates that enterprising career interests require visual intelligence space. A significant positive correlation between intrapersonal and enterprising $(\mathrm{r}=.277, \mathrm{p}<.05)$. This finding indicates that enterprising career interests require intrapersonal.

In addition, the findings also show there is a significant positive relationship between personality conventional and naturalist $(\mathrm{r}=.250, \mathrm{p}<.05)$. There is also a significant positive correlation between intrapersonal with conventional $(r=.277, \mathrm{p}<.05)$. These findings demonstrate that conventional career interests require naturalist intelligence and intrapersonal. 


\begin{tabular}{lcccccc}
\hline \multicolumn{1}{c}{ Multiple } & \multicolumn{5}{c}{ Career Interest } \\
\cline { 2 - 7 } Intelligence & Realistic & Investigative & Artistic & Social & Enterprising & Convensional \\
Mathematical & .009 & .150 & -.054 & .111 & .063 & .017 \\
Logic & -.003 & .173 & -.175 & -.142 & .048 & .085 \\
Visual-Space & $.425^{* *}$ & $.262^{*}$ & .207 & .156 & .209 & .168 \\
Music & .196 & .188 & $.252^{*}$ & .109 & .029 & -.205 \\
Naturalist & $.366^{* *}$ & $.420^{* *}$ & .180 & $.376^{* *}$ & $.259^{*}$ & $.250^{*}$ \\
Kinesthetic & $.436^{* *}$ & .099 & .204 & $.322^{* *}$ & $.336^{* *}$ & .152 \\
Interpersonal & $.290^{*}$ & $.358^{* *}$ & .170 & $.388^{* *}$ & $.266^{*}$ & .206 \\
Intrapersonal & $.229^{*}$ & $.379^{* *}$ & .133 & $.367^{* *}$ & $.277^{*}$ & $.277^{*}$ \\
Existential & .142 & .169 & .055 & $.314^{* *}$ & .125 & .120 \\
\hline
\end{tabular}

$\mathrm{P}<.05^{*}, \mathrm{P}<.01^{* *}$

can correlate between life can improve investigative

\section{DISCUSSION}

Realistic personality shows an individual has characteristics such as not social, natural, practical and flexible. These characteristics correspond to the work environment such as mechanics, engineers and others (Holland, 1985). In other words, realistic personality would choose a job that is object-oriented and not human oriented (AmlaSalleh, 2010; Noah Sidek, 2002). Tthis study found that those who have a realistic personality has a relation with visual space intelligence, naturalist, kinesthetic, interpersonal and intrapersonal. For example, intelligence requires a visual space, capable of doing the technical work such as in realistic personality. Similarly, kinestatic intelligence uses coarse or fine psychomotor skills needed for a career in a realistic environment. These findings illustrate to strengthen realistic personality characteristics requires an increase in visual space intelligence, naturalist, kinesthetic, interpersonal and intrapersonal. This will produce a consistent career and personality congruent with the career environment and contribute to career satisfaction (Holland, 1996; Savickas, xxxx).

Investigative personality shows an individual has characteristics such as a detail observer and aware of the environment and being able to make a selfassessment. These characteristics correspond to the work environment as a scientist, forensic experts and others (Holland, 1985). In other words, investigatifpersonality incline to choose a job based on the work environment requiring research skills, scientific, intellectual, analytical, accurate, like to observe, learn, research, analyze, evaluate and solve problems (AmlaSalleh, 2010; Noah Sidek, 2002). This study found that those who have investigative personality has a relation with visual space intelligence, intrapersonal and naturalist. Visual space intelligence requires an individual able to think imaginatively, images, shapes to form a visual model and apply the model to the physical world that is very appropriate to the investigative personality. Naturalist intelligence shows someone who is sensitive to the environment and personality. Intrapersonal intelligence that uses high self-awareness about the ability to monitor the thoughts, actions and feelings are very helpful in the formation of an investigative personality. These findings reflect the strengthening features of investigative personalitywhich requires an increase in visual space intelligence, intrapersonal and naturalist.

Artistic personality shows a person's characteristics are a creative person and have a high appreciation and respect for the creative art work environment that requires high power intuition, expressive, less structured, non-routine and non-repetitive. These features are consistent with the work of the author creative arts, interior decorators and others. The findings show artistic personality have a positive relationship with the intelligence of a variety of music. Musical intelligence requires the ability to think in the form of a musical, listen and recognize patents as well as in noise-sensitive environments. This finding reflects to strengthening features of artistic personality requires an increase in musicintelligence.

Social personality indicate that the individual has the characteristics of a person who has the skills to interact and communicate with others, helpful, provide services and solve social problems. For those jobs that require the interaction of cooperation, collaboration, mutual help, training and welfare to others. Features accordance with the work of teachers, counselors, nurses and others. Results showed that social personality have a positive relationship with naturalist intelligence, kinesthetic, interpersonal, intrapersonal, visual and existential space. Naturalist intelligence shows someone who is sensitive to the environment and can correlate between life can improve the personality of social. Kinestheticintelligence is the ability to use some or all members of the body to communicate and solve problems to have a positive relationship to strengthen the personality of social. Interpersonal intelligence involves one's skills to communicate, build relationships and build trust with others. Intrapersonal intelligence that uses high self-awareness about the ability to monitor the thoughts, actions and feelings are very helpful in the formation of social personality and 
visual-spatial intelligence requires an individual is able to think imaginatively, images, shape to form a visual model and apply the model to the physical world that is very compatible with the social personality. Existential intelligence is the ability to understand and arbitrate philosophical matters relating to the existence of God and the nature of life. This finding reflects the strengthening of social personality traits requires an increase in the naturalist intelligence, kinesthetic, interpersonal, intrapersonal, visual spatial and existential.

Enterprising personality shows an individual has characteristics such as friendly, optimistic, lead and manage others and sell goods or ideas. Working environment involving administration and management, business and entrepreneurship. Suitable jobs are managers, entrepreneurs and others. The findings showed naturalist intelligence are sensitive to the environment and can correlate between life can improve enterprising personality. Kinesthetic intelligence is the ability to use some or all members of the body to communicate and solve problems is to have a positive relationship to strengthen enterprising personality. Interpersonal intelligence involves communicating one's skills, relationships and build trust with other people needed in an enterprising personality. Visual intelligence space requires an individual able to think imaginatively, images, shapes to form a model for visual and apply the model to the physical world that is very compatible with the personality enterprising, intelligence intrapersonal the use of self-awareness high about the ability to monitor your thoughts, actions and feelings are very helpful in the formation of enterprising personality. These findings clearly illustrate to strengthening enterprising personality characteristics, a person needs to improve intelligence in naturalist, kinesthetic, interpersonal, intrapersonal and visual space. This will enable to form consistent career personality and congruent with career environment and contribute to career satisfaction (Holland, 1996; Savickas, xxxx).

Conventional personality indicates characteristics of structured, rigorous, regular and high durability. Structured and organized work environment involving data, numbers and clerical work in detail. Findings show that conventional personality has positive relationship with the naturalist intelligence and intrapersonal. Naturalist intelligence shows someone who is sensitive to the environment and can correlate between life can improve conventional personality. Intrapersonal intelligence that uses high self-awareness about the ability to monitor the thoughts, actions and feelings are very helpful in the formation of conventional personality. Results clearly show naturalist intelligence and intrapersonal should be intensified to strengthen conventional personality.
Seach individual has all kinds of intelligence but on the degree or different rate in strengths and skills. Intelligence can be developed through education, experience and environment. Selection of education course and careers increasingly complicated due to various human abilities. In addition, the rapid progress experienced by the country has led to specialized areas of employment and education is growing. The growth area of specialization is largely due to the country's economic system is increasingly complex. The problem of choosing a career is a problem most often cited by teens. The main problem of the occurrence of difficulties in making a career choice among students and young people is not decided, the fault when making a choice and lack of knowledge and information about jobs and careers. Process to guide students to goals which best fit with interest, value, personality and ability is complicated, challengeing and requires a lot of time.

\section{CONCLUSION}

Generally, we can see the relationship of multiple intelligences and career interests are not extensive to all the constructs of multiple intelligences but it shows a clear connection with the career interestconstructs. Each construct of career interests has positive relationship for at least a construct of multiple intelligences. Findings of this study can be used for an intervention program designed to strengthen requirements between multiple intelligences and career interest so that it really can help students, especially students of Form 3 before selecting the stream in Form 4. The results of the individual in choosing an education or job stream can be accurate and also likely to be inaccurate depending on the maturity of pupils and guidance obtained before deciding. However, choice or decision made by the students, an effective electoral system practiced by the school should be able to identify potential in students with the chosen stream. An effective electoral system should only accept suitable candidates and reject candidates or distribute themto stream that will better suit the interests and preferences of students and not solely based on PT3 results of the student.

Linguistic and mathematical showedno relationshipith any career interestconstructs. Is it linked to the readiness of the respondents to answer the questions? Are linguistic and mathematical intelligence being not a requirement in the selection of career interests?

\section{REFERENCES}

[1] Amla Mohd. Salleh. 2007. Pendidikan Kerjaya dan Pembangunan Modal Insan. Bangi: Penerbitan Universiti Kebangsaan Malaysia. Selangor.

[2] Binet. 1905 .dalam Wolf, T.H. 1969. , The emergence of Binet's conception and measurement of intelligence: a case history of the creative process, 
Journal of the history of the behavioral sciences (Apr 1969) 5 (2): 113-34.

[3] Gardner, H. 1993. Frame Of Mind: The theory of multiple intelligences. New York, NY: Basic Book.

[4] Gardner, H. 1983. Frames of Mind. New York: Basic Books Inc.

[5] Gardner, H. 1999. Intelligence Reframed.USA: Basic Books.

[6] Holland, J.L. 1996. Making Vocational Choice: A Theory of Vocational Personality and Work Environment. Edessa, Florida: Psychological Assessment Resources.

[7] Holland, J. L. 1973. Making Vocational Choice: A Theory of Career. Englewood Cliff, New Jersey: Prentice Hall Inc.

[8] Holland, J. L. 1985. Manual for the Vocational Preference Inventory. Odessa, Florida: Psychological Assessment Resources.

[9] Iskandar Rohaty Mohd. Majzub Zuria Mahmud. 2009. Kecerdasan Emosi dan Komitmen Pekerjaan dalam Kalangan Pensyarah Universiti di Indonesia. Jurnal Pendidikan Malaysia 34(1) (2009): 173 - 186

[10] Kamus Dewan. 2005. Kuala Lumpur: Dewan Bahasa dan Pustaka.

[11] Kementerian Pendidikan Malaysia. 2012. Manual Pentaksiran Psikometrik. Lembaga Peperiksaan.

[12] Kementerian Pendidikan Malaysia. 2012. Inventori Minat Kerjaya. Lembaga Peperiksaan.

[13] Kementerian Pendidikan Malaysia. 2013. Pelan Pembangunan Pendidikan Malaysia -2013-2025.

[14] Meers, G., \& Wiseman, K. 2002. Designed successful learning. The Science Teacher, 69(8), 29-31.

[15] Mohd Kashfi b. MohdJailani, Siti Rahayah Ariffin, Rosseni Din, Bishanani Omar \&Sarimah Mokhtar. 2001. Kecerdasan Pelbagai Dalam Kalangan Murid Universiti Awam Malaysia Fakulti Pendidikan, Universiti Kebangsaan Malaysia

[16] Nuramirah Zaini, Norizan Abdul Razak. 2013. The Correlation between Multiple Intelligence Scores and English Language Reading Skill among Business Management Students. Prosiding Simposium Kebudayaan-Indonesia Malaysia, Volume 13. Universiti Kebangsaan Malaysia

[17] Sidek Mohd Noah. 2002. Perkembangan Kerjaya: Teori dan Praktis. Universiti Putra Malaysia, Serdang, Selangor Darul Ehsan.

[18] Siti Rahayah Ariffin Roseni Ariffin Arbaiyah Md Zin Nik Noralhuda Nik Mohamed. 2011. Kajian Faktor Kecerdasan Pelbagai Dalam Pembentukan Profil Remaja Malaysian Journal of Learning and Instruction: Vol. 8 (2011): 183-204

[19] Wahyudi. 2016. Kajian KecerdasanVokasional Dari Persepsi Murid Sekolah Menengah Teknik: Satu Kajian Kes Di Negeri Perak Tesis Dikemukakan Bagi Memenuhi Syarat Untuk Memperoleh Ijazah Sarjana Sains (Pendidikan Teknikal Dan Vokasional) Universiti Pendidikan Sultan Idris.

[20] Yi-an, H. 2010. Multiple Intelligences and Foreign Language Learning- A Case Study in Taiwan. WHAMPOA- An Interdiscplinary Journal, 1. 